\title{
The Practice and Contemporary Revelation of the Regime Construction of "Three-thirds System” in Shaanxi - Gansu - Ningxia Border Region
}

\author{
Li Lihe
}

Municipal Party School in Qingyang Gansu, Qingyang, Gansu

Keywords: three-thirds system; regime construction; contemporary enlightenment

\begin{abstract}
Three-thirds system" was the first anti-Japanese democratic regime created by the Communist Party of China (CPC) in Shaanxi-Gansu-Ningxia Border region during the Anti-Japanese War, and it was a great pioneering undertaking in the history of China's revolutionary construction. It is also a successful example of the Communist Party of China in the construction of political power. The practice and exploration of studying "Three-thirds system " democratic regime still has important reference in the new period and enlightens for perfecting the construction of the political power of the CPC today.
\end{abstract}

\section{Introduction}

During the War of Resistance against Japan, “three-thirds system " regime established and led by the Communist Party of China in the anti-Japanese base areas behind the enemy lines, it was an anti-Japanese democratic regime established according to the needs of the situation of the War of Resistance against Japan at that time. During the War of Resistance against Japan, it played a great role in mobilizing all positive factors to participate in the War of Resistance against Japan. Its basic thought and practice have important practical significance for the later political construction of the Communist Party of China and the construction of political power today.

\section{Practical Exploration on the Construction of "three-thirds system " Democratic regime in Shaanxi-Gansu-Ningxia Border region}

The cannon kindled the flames Chinese war in Lugou Bridge in July 7, 1937, the ethnic conflicts became the main contradiction between the Chinese people and the Japanese imperialist. In the face of the national crisis of the Japanese invaders trying to destroy China, under the obvious situation of the strong enemy and the weak, China can not defeat the Japanese invaders without the general mobilization of the whole nation. Therefore, CPC Central Committee regards the realization of democracy as an important condition and a guarantee of victory in the War of Resistance against Japan, and gives the people the democratic rights of speech, publication, assembly, association and participation in government affairs, so that the War of Resistance against Japan becomes people's war. In a word, put an end to one-party dictatorship and formed a coalition government including all parties. But in the early days of the war, the main anti-Japanese base with a noticeable problem in power system was established in the state organs at various levels are the main Communist in the bear as a leader, the other class members were relatively few, which was unfavorable for the unity and anti Japanese war. Therefore, it was urgent to create a new political power mode. "Three-thirds system " adapted to the needs of the war in such a historical context and came into being in Shaanxi-Gansu -Ningxia border region.

In order to attract more people to the banner of the anti-Japanese national united front, the Communist Party of China first implemented the "Democratic Republic" program of nation-building in the anti-Japanese base areas under its leadership. In March 11th 1940, Mao Zedong's report on the Strategy in the present Anti-Japanese United Front further clarified the meaning of "three-thirds system " policy and the requirement that the Communist Party should cooperate with other parties. He said " the personnel allocation regime should be the Communist Party members accounted for $1 / 3$, representing the proletariat and the poor; the left advance sub 
accounts for $1 / 3$, they represent the petty bourgeoisie; the middle and other elements accounted for $1 / 3$, representing the middle the bourgeoisie and the enlightened gentry. Traitors and anti communist elements that are not eligible to participate in this regime." since then, Mao Zedong has repeatedly discussed "three-thirds system"; which was to make "three-thirds system" regime become a united front democratic regime based on a broader social basis.

"Three-thirds system" democratic regime in Shaanxi-Gansu-Ningxia Border region has mainly carried on the practice exploration in the following aspects. The first aspect was the electoral system. The election qualification, provisions of all sectors of the masses were universal, equal right to vote and to be elected. In Shaanxi Gansu Ningxia border region, lived in the border region people, at least eighteen years old, regardless of class, party and occupation, men and women, nationality, religion, property, cultural difference, had the right to vote and stand for election. The general election qualification, equality, widely expanded "mass base three-thirds system" regime. In the election, the implementation of direct and indirect election directly combined. According to the internal elections, the implementation of indirect election guerrilla zones, adopted a secret ballot method. In addition, the Anti Japanese base areas were generally implemented the public campaign, was a great creation of three-thirds system ". The second aspect was a Council and government system. In "three-thirds system", the Council was the public authority and authority, the government was the administrative organ and executive organ. The Council elected by the government, the government should respect the Council's resolution, and subject to the supervision of the staff; the government was incompetent, to play by the Senate to impeach, dismissed. The government in all the border region government, and relatively independent. Therefore, "three-thirds system" government was a kind of political power with high adaptability and flexibility, in which the Senate and the government are independent and mutually restrict each other. The third is the party system. "Three-thirds system" has the following characteristics. (1) all anti-Japanese parties legitimate rights were entitled to adequate legal protection; (2) the Communist Party followed the mutual encouragement and mutual respect, mutual forgiveness, stood together through storm and stress, worked together with one heart principle, sincerely cooperated with other parties to plan, and the Communist Party The other party is an exploration of new friends of the party, not one or two parties system; (3) in the government in fact only the Communist Party has absolute ruling ability and leadership, but the leadership was not the law privileges, only the Communist Party member quality must be greatly improved in order to achieve the leadership of the Communist Party of the right.

\section{The Historical function of "three-thirds system" in Shaanxi - Gansu - Ningxia Border region}

\subsection{It has promoted the realization of China's political democratization and improved and strengthened the party's leadership over political power}

The historical role of" three-thirds system" lies first in the fact that it has enabled the anti-Japanese base areas to realize a new-democratic democratic politics, prominent among which is the new election principle. Its electoral law clearly stipulates that all Chinese people who have reached the age of 18 are of no distinction between men and women. Differences in faith and education, as long as they are not traitors, anti-Communists, and the mentally ill, have the right to vote and stand for election. This universal, equal and direct democratic election, conducted from the bottom up, it has laid the foundation stone of the democratic nature of" three-thirds system”, which is a great contribution of the Chinese Communists to the realization of China's political democratization. At the same time, because of the establishment of "three-thirds system" democratic regime, it has been generally supported by the broad patriotic and anti-Japanese classes and strata. Therefore, does not mean to reduce or weaken the party's leadership over the regime, but to ensure and improve the leadership of the party. 
3.2 The relations between the various anti-Japanese classes and strata have been coordinated, and the anti-Japanese enthusiasm of all parties has been aroused

"Three-thirds system" said that the other $2 / 3$ other than the Communist Party included all parties, factions, people from all walks of life and non-party personages. The spirit of multi-party cooperation was preliminarily embodied here. Of course, non-party people are elected to power. It was not a matter of dressing them up as a decoration, but rather of paying attention to listening to their correct views and formulating policies that properly take care of their interests. This fully demonstrated the sincerity of the Communists in uniting and cooperating with the non-Party personages, and reflected the broad mind of the Communists; at the same time, they had also effectively won over the middle forces and isolated the diehard forces. We had fully aroused the enthusiasm of all strata of the anti-Japanese class.

\subsection{The system of multi-party cooperation and political consultation has been tried}

"Three-thirds system" occupies an important position in the history of political power development in our country. It is the embryonic form of the new Chinese regime. In fact, it is also the predecessor of the multi-party cooperative system under the leadership of the Communist Party. Before and after the founding of the People's Republic of China, drawing on the successful experience in the construction of "three-thirds system", our party duly proposed in the "Common Program" of the Chinese people's political Consultative Conference the establishment of a political power under the people's democratic dictatorship, thus creating a system of multi-party cooperation and political consultation. They contributed to the victory of the New Democratic Revolution and the birth of New China. After the founding of New China, all democratic parties clearly declared that they would accept the leadership of the Communist Party. Supporting the "Common Program" and the "Constitution of the people's Republic of China," and participating in the management of state affairs and consultations on major issues in the country's political life, actually formed a system of multi-party cooperation and political consultation under the leadership of the Communist Party.

\section{4 “Three-thirds system” has been an Exploration of Power balance Mechanism}

"Three or three systems" regime is a good exploration of the power balance mechanism. On the one hand, it Qingyang, Gansuis the power restriction within the regime. "Three-thirds system" are a large system and the three " $1 / 3$ " regimes in the regime are subsystems. The three subsystems belong to different classes and strata, and the people in each subsystem should try to realize their own interests without exceeding a certain limit. Otherwise, they will be restrained or sanctioned by the other two subsystems. What is more important was that 2/3 of the non-party personages had formed supervision and restriction on the Communist Party, in order to ensure its political prestige and leadership position in the regime, we must be more strict with ourselves and be in close contact with the broad masses. On the other hand, it was the power restriction outside the regime. The power distribution mode of "three or three systems" regime indicated that the regime must be under external supervision and restriction. In the election, all government organs and personnel who were divorced from the masses, oppress the people, be superior to the public, and do not respect the rights of the people, will be spurned by the public, thus forming a powerful control over bureaucracy, corruption, and self-indulgence.

\section{The Enlightenment of the Construction of "three-thirds system" Democratic regime to the Construction of Contemporary regime in Shaanxi-Gansu-Ningxia Border region}

\subsection{Democracy must be put first in the Construction of political Power}

Democracy is the core of "three-thirds system". Three-thirds system" democratic regime was a new exploration of our party's political power construction during the special period of the Anti-Japanese War. It not only guides the Party's correct path in the period of the War of Resistance against Japan, After the founding of the people's Republic of China, after the founding of the 
people's Republic of China, the political and economic retrogression caused by the destruction of democracy inside and outside the Party, our party has a deeper understanding of the importance of building democratic regimes. Deng Xiaoping stressed that without democracy, there would be no socialism. At the 65th anniversary of the CPPCC session on 2014, Jin-ping Xi said: "under China's socialist system, find the greatest common denominator of the wishes and demands of the whole society. It was the true meaning of people's democracy, which shows that "democracy" was an important guarantee for safeguarding our party's ruling position, uniting the broad masses of people to smoothly complete the reform and opening up, and realizing the grand goal of building a well-off society in an all-round way.

\subsection{Democracy Construction of political Power must be legalized}

The construction of "three-thirds system" has given the Communist Party of China a broad basis of public opinion and further realized its own political legitimacy. In the construction of the anti-Japanese democratic regime, the party has participated in government affairs and discussed government affairs and conducted democratic consultations. The basic principle of democratic supervision plays the role of uniting the people, cracking down on the enemy, and promoting the smooth progress of the War of Resistance against Japan. In particular, the "Common Programmer" adopted by the first Chinese people's political Consultative Conference and the "Constitution of the people's Republic of China" adopted by the first National people's Congress set out the guidelines of the Communist Party of China in the form of the fundamental law of the country. The system of multi-party cooperation and political consultation is one of the three basic political systems in China. At the 60th anniversary of the founding of the National people's Congress, Jin-ping Xi stressed that to develop people's democracy, we must run the country according to law, uphold the authority of the Constitution, institutionalize and legalize democracy, so that this system will not change with the change of leaders. It does not change with the change of opinion and attention of the leaders.

\subsection{Democratic Supervision and effective checks and balances must be carried out in the Construction of political Power}

The principle of power balance was a political experience accumulated by human beings for thousands of years, an important rule to prevent abuse of power, and an inevitable requirement for the development of democratic politics. Power is bound to become corrupt. Some of the corruption that has occurred in recent years has seriously hindered the process of reform and opening up and the building of democratic politics. The main reason for power corruption lies in the lack of an effective mechanism of supervision and balance. The construction of "three-thirds system" provides many lessons for reference for the establishment of effective checks and balances, democratic and efficient ways of political power operation. The main points are as follows: first, in the way of leadership of the ruling party, it was necessary to change from replacing the law with words and replacing the government with the rule of law, and administrating according to law, and changing the situation of the party "taking the place of everything and arranging everything". Second, in the construction of political power, we should reduce the excessive proportion of party members in the people's congresses at all levels, expand the political participation of the masses, and make the people's congresses at all levels truly organs of public opinion and power. Third, in the political party system, we should strengthen and improve the system of multi-party cooperation and political consultation. Make it an effective form for all classes, strata, democratic parties and people's organizations within the people to exercise democratic supervision. In the difficult years of "subjugation and extinction", our Party "took the world as its duty" and held "unity and democracy". The banner of "progress" creatively built "three-thirds system" under the joint dictatorship of all classes and all strata, and allowed 2/3 non-Party people to supervise it, and there was no phenomenon of "inefficiency and prevarication". On the contrary, under the extremely cruel conditions of war, our party, with great political vigor and strong determination to fight for democracy and freedom, aroused the patriotic enthusiasm of millions of people to unite in the war of resistance and to establish a democratic foundation. He won the great victory of the War of Resistance against Japan, and won the masses and popular support for the founding of New China. 
Therefore, in the current unprecedented struggle against corruption, Jin-ping Xi pointed out: "We should let the people supervise power and let it run in the sun." Put power in the cage of the system, and strive to create a clean and upright style of party and government conduct and social ethos. "This was undoubtedly a basis for our party to sum up the experience and lessons of democratic construction," he said. In short, "three-thirds system" was an important exploration in the history of political power construction of our party, and valuable experience in the construction of "three-thirds system" will contribute to the future construction of the democratic regime of the Communist Party of China. Consolidation and development have important practical significance.

\section{References}

[1] Mao Zedong anthology, vol. 2, people's press, 1991, 750-751.

[2] Mao Zedong anthology, vol. 2, people's press, 1991, 742.

[3] Selected documents on legal system in Revolutionary Base areas, vol. 2, China Science Press, 1986, 338

[4] Government documents in the Shaanxi-Gansu-Ningxia Border region, Archives Press, 1986, 156-158.

[5] Selected works of Mao Zedong, vol. 3, 1991,808

[6] Deng Xiaoping anthology, vol. 2, people's press, 1994, 328 - 329. 